\title{
In-vitro Activities of Daptomycin in Combination with Rifampicin and Gentamicin Against VRE Strains
}

\section{Daptomisinin Rifampisin ve Gentamisin ile Kombinasyonlarının VRE Sușlarına in-vitro Etkinliği}

\author{
Gülseren Aktaș, Șengül Derbentli \\ Istanbul University, Istanbul Faculty of Medicine, Department of Medical Microbiology, Istanbul, Turkey
}

\begin{abstract}
AIM: In-vitro activity of daptomycin in combination with rifampicin and gentamicin, was assessed against vancomycin-resistant enterococci (VRE) with both high-level aminoglycoside resistance (HLAR) and non-HLAR.

METHODS: Identification of 39 VRE was performed using conventional methods. HLAR strains were identified by using disk diffusion method with gentamicin: $120 \mu \mathrm{g}$ and streptomycin: $300 \mu \mathrm{g}$ disks. The rates of HLAR and non-HLAR were established as $41 \%$ (16/39) and 59\% (23/39), respectively.

Minimum inhibitory concentration (MIC) of all antibiotics used were determined and evaluated using microbroth dilution technique as described by Clinical and Laboratory Standards Institute (CLSI).

In-vitro activities of antibiotic combinations were determined using microbroth "checkerboard" microdilution technique. Fractional inhibitory concentration index (FICl) were calculated relative to MIC values of antibiotics both alone and in combinations. Synergy was defined as a $\mathrm{FICl}$ of $\leq 0.5$, additive/indifference as a $\mathrm{FICl}>0.5-4.0$ and antagonism as a $\mathrm{FICl}$ of $>4.0$.
\end{abstract}

RESULTS: All strains were established as daptomycin susceptible (100\%) while rifampicin susceptibility rate was found to be $5.1 \%$ (2/39) according to MICs. When daptomycin was combined with rifampicin and gentamicin, additive/indifferent effects were observed for the majority of 39 strains, even though the synergistic effect defined in non-HLAR were $34.8 \%$ and $8.7 \%$, respectively. Although daptomycin combination with rifampicin showed a synergistic effect against $50 \%$ of HLAR, no synergism was observed in combination of daptomycin with gentamicin. The combinations of both daptomycin/rifampicin and daptomycin/gentamicin also showed FICl of 0.155-1.5 and 0.375-2 against strains, respectively. There was no antagonism observed in any of the combinations.

CONCLUSION: The results of the study suggest that the combination of daptomycin/rifampicin may be recommended as an alternative in treatment of serious VRE infections caused by both HLAR and non-HLAR.

Key words: antimicrobial combinations; vancomycin-resistant-enterococci; "checkerboard" microdilution technique

Doç. Dr. Gülseren Aktaş, Istanbul Tip Fakültesi, Temel Tip Bilimleri, Tibbi Mikrobiyoloji Anabilim Dall, Capa, 34093 İstanbul, Türkiye

Tel.05553794557Email.gulserena2001@yahoo.co.uk

Geliş Taribi: 05.03.2015 • Kabul Tarihi: 29.08.2016
ÖZET

AMAÇ: Daptomisinin, rifampisin ve gentamisin ile kombinasyonlarının, hem yüksek düzeyde aminoglikozid direnci (HLAR) olan ve hem de HLAR olmayan (non-HLAR) vankomisine dirençli enterokok (VRE) sușlarına karșı etkinliği in-vitro koșullarda araștırılmıștır.

YÖNTEM: Otuz dokuz VRE sușunun laboratuvar tanısı konvansiyonel yöntemler ile yapılmıștır. HLAR araștırması için $120 \mu \mathrm{g}$ gentamisin ve $300 \mu \mathrm{g}$ streptomisin içeren diskler kullanılarak yapılan difüzyon yöntemi sonucunda; sușların \%41'inin (16/39) gentamisin ve streptomisine yüksek düzeyde dirençli (HLAR) ve \%59'unun (23/39) ise duyarlı (non-HLAR) olduğu belirlenmiștir.

Çalıșmada kullanılan tüm antibiyotiklerin minimum inhibitör konsantrasyon (MiK) değerleri, Clinical and Laboratory Standards Institute (CLSI)'ın önerileri doğrultusunda, buyyonda mikrodilüsyon yöntemi ile belirlenmiș, sonuçları aynı standarda göre değerlendirilmiștir.

Antibiyotik kombinasyonlarının in-vitro aktivitesi "checkerboard" mikrodilüsyon tekniği kullanılarak saptanmıștır. Çalıșmada kullanılan sușlar için, antibiyotiklerin tek bașına ve kombinasyon halinde iken elde edilen MiK değerlerine göre fraksiyonel inhibitör konsantrasyon indeks (FiKi) değerleri hesaplanmıștır. Buna göre FiKi $\leq 0,5$ olarak buIunan sonuçlar sinerjist; FIKI >0,5-4,0 additif/indifferens; ve FiKi >4,0 olarak bulunan sonuçlar ise antagonist etki olarak değerlendirilmiștir.

BULGULAR: Sușların tümü (\%100) daptomisine duyarlı bulunurken, rifampisine duyarlılı oranı ise \%5,1 (2/39) olarak tespit edilmiștir. Daptomisinin, rifampisin ve gentamisin ile kombinasyonları non-HLAR sușlarının sırasıyla \%34,8 (8/23) ve \%8, 7'si (2/23) için sinerjist etkili bulunmasına karșın, sușların çoğunluğu için additif/indifferens etkili saptanmıștır. Daptomisinin rifampisin ile kombinasyonu HLAR sușlarının \%50'si (8/16) için sinerjist etkili bulunurken, daptomisinin gentamisin ile kombinasyonunun, sușların hiçbiri için sinerjist etki sağlamadığı gözlenmiștir. Tüm VRE sușları için daptomisin/rifampisin ve daptomisin/gentamisin kombinasyonlarının FiKi değerleri sırasılla 0,155-1,5 ve 0,375-2,0 olarak belirlenmiștir. Her iki antibiyotik kombinasyonunun da, çalıșmada denenen VRE sușlarının hiçbiri için antagonist etki göstermediği saptanmıștır.

SONUÇ: Çalıșmanın sonuçları, hem HLAR ve hem de non-HLAR VRE sușları tarafından olușturulan ciddi VRE enfeksiyonların tedavisinde daptomisin/rifampisin kombinasyonunun önerilebilir bir alternatif olduğu fikrini vermiștir.

Anahtar kelimeler: antimikrobiyal kombinasyonları; vankomisine dirençli enterokoklar; "checkerboard" mikrodilüsyon tekniği 


\section{Introduction}

In recent years, there has been a worldwide increase in the incidence of hospital- and community-acquired infections caused by antibiotic resistant Gram-positive bacteria, including vancomycin-resistant enterococci (VRE) and methicillin-resistant Staphylococcus aureus (MRSA). Although new generation antimicrobial agents have been used in the treatment of infections caused by multidrug-resistant Gram-positive cocci, resistance to antibiotics has been emerging and spreading ${ }^{1,2,3}$. New antibiotics are few in number and they have limited effect mechanisms $s^{4}$. The main reason of resistance of bacteria to antibiotics is the frequent and random use of them. Emergence of vancomycinresistant strains as well as the increase of enterococci infections has led to greater problems. New antibiotics quinupristin-dalfopristin, linezolid, daptomycin, and tigecycline have been introduced into clinical usage as a result of increasing incidence of VRE strains. However, enterococci have also developed some resistance to these new-generation antibiotics 5 . Therefore, it is essential to develop new antimicrobial agents that would be effective against multidrug-resistant Grampositive pathogens. Resistance could develop against new antibiotics such as daptomycin due its overuse. Therefore, they are recommended only in cases of vancomycin-resistant Gram-positive bacterial infections ${ }^{6}$.

Daptomycin is the primary and single member of new antibiotic group known as cyclic lipopeptides and has bactericidal activity against Gram-positive bacteria including VRE and MRSA ${ }^{7}$. It attaches to the cytoplasmic membrane of Gram-positive bacteria in the existence of calcium and generates canals in the membrane. This causes some small potassium-like ions to move towards the extracellular fluid, and depolarization of the cell membrane. Thus, protein, DNA and RNA synthesis are inhibited, and rapid bacterial death occurs but the integrity of the cell is preserved as lysis is prevented. Daptomycin has a long-lasting post-antibiotic effect ${ }^{8}$.

At present, antimicrobial agents have increasingly been used in combinations to inhibit or delay the emergence of resistant subpopulations during the treatment of infectious diseases. Use of antibiotic combinations in treatment can also provide a wide-spectrum effect. Because daptomycin has a different effect mechanism on microorganisms it has no cross resistance to other antimicrobial agents. It makes daptomycin the single choice in treatment of infections caused by multidrug-resistant bacteria. Additionally, interaction of daptomycin with other antimicrobial agents could be promising in treatment. Therefore, more combination studies should be performed?

In the present study, we aimed to investigate the invitro activity of daptomycin alone and in combination with rifampicin and gentamicin using checkerboard microdilution method.

\section{Material and Methods}

In this study, we had used 39 VRE strains, each of which was isolated from rectal swab samples of inpatients of various departments in our hospital.

The swab samples were cultivated in an azide-dextrose broth (Merck, Germany), and were incubated overnight at $35^{\circ} \mathrm{C}$ to investigate the presence of VRE. The samples were then cultivated in trypticase soy agar (TSA; Oxioid, England), which included $6 \mu \mathrm{g} / \mathrm{ml}$ vancomycin, and were incubated for 24 to 48 hours in same conditions. Conventional methods were used to identify of the cultivated bacteria ${ }^{10,11}$. Strains were identified as Enterococcus spp. if they had the following properties: Gram-positive; catalase negative; ability to grow in 6.5 sodium chloride, $40 \%$ bile, and hydrolyzed esculin; and positive results of pyrrolydonyl arylamidase tests (PYR; BD; USA). Resistance to vancomycin was investigated by disk diffusion ( $30 \mu \mathrm{g}$; Oxoid, England). Resistance to vancomycin was verified by microdilution method and these strains were classified as VRE.

High level of aminoglycoside resistance among VRE strains were investigated using $120 \mu \mathrm{g}$ gentamicin and $300 \mu \mathrm{g}$ streptomycin (BD BBLTM BENEX Ltd., Ireland) disks. Gentamycin sensitivity results were verified by microdilution. Minimum inhibitory concentrations (MIC) of antibiotics were identified using microdilution method in accordance with the Clinical and Laboratory Standards Institute (CLSI) recommendations.

Raw materials of daptomycin (Novartis Pharma AG, Switzerland), rifampicin (Nobelfarma Inc. Düzce) and gentamicin (Bilim Medicine Inc., İstanbul) were provided by manufacturing companies and the solutions were prepared in accordance with the recommendations of the CLSI. Mueller-Hinton broth supplemented with $12.5 \mu \mathrm{g} / \mathrm{ml}$ magnesium and $50 \mu \mathrm{g} / \mathrm{ml}$ calcium was used as a dissolvent and diluent, and also as a medium. After overnight incubation at $35^{\circ} \mathrm{C}$, the MICs were recorded as the complete inhibition of visible growth in the wells. The evaluations of the results 
were made in accordance with the breakpoint values of the CLSI. Staphylococcus aureus ATCC 29213 and Enterococcus faecalis ATCC 29212 reference strains were used as a quality control in the experiment ${ }^{11,12}$.

Activities of the antibiotic combinations were investigated by using checkerboard microdilution method ${ }^{10}$. For each strain, antibiotic concentrations were prepared according to two dilutions above and four dilutions below the determined MIC values. Combination solutions were obtained by diluting one antibiotic horizontally and one antibiotic vertically on microtitre plates. Bacterial suspensions were added at a density of $5 \times 105 \mathrm{CFU} / \mathrm{ml}$. After overnight incubation of the plates at $35^{\circ} \mathrm{C}$, the lowest concentration at which strains growth inhibited in combination was determined, and divided the MIC value alone to get the fractional inhibitory concentration (FIC). Then, the FIC index (FICI) value for each strain was measured. The results were evaluated as FICI $\leq 0.5$ synergistic, FICI $>0.5-4$ additive/indifference (no interaction), and FICI $>4$ antagonistic ${ }^{13}$.

\section{Results}

In this study, 16 (41\%) of 39 VRE strains were identified as high-level aminoglycoside resistant (HLAR) and 23 (59\%) as non-HLAR strains.

All examined VRE strains were found sensitive to daptomycin. Daptomycin $\mathrm{MIC}_{50}, \mathrm{MIC}_{90}$, and $\mathrm{MIC}_{\text {range }}$ values were $1 \mu \mathrm{g} / \mathrm{ml}, 2 \mu \mathrm{g} / \mathrm{ml}$, and $0.2-2 \mu \mathrm{g} / \mathrm{ml}$ in all strains, respectively. When the values were evaluated separately as HLAR and non-HLAR, they were identified as $1 \mu \mathrm{g} / \mathrm{ml}, 2 \mu \mathrm{g} / \mathrm{ml}$, and $1-2 \mu \mathrm{g} / \mathrm{ml}$, and $1 \mu \mathrm{g} /$ $\mathrm{ml}, 1 \mu \mathrm{g} / \mathrm{ml}$, and $0.2-2 \mu \mathrm{g} / \mathrm{ml}$, respectively (Table 1 and 2). MIC ${ }_{\text {range }}$ values among the HLAR strains were identified as $1 \mu \mathrm{g} / \mathrm{ml}$ for nine of the strains and $2 \mu \mathrm{g} /$ $\mathrm{ml}$ for seven of the strains, whereas one of non-HLAR strains was identified as $0.2 \mu \mathrm{g} / \mathrm{ml}$, two strains as 0.5 $\mu \mathrm{g} / \mathrm{ml}, 18$ strains as $1 \mu \mathrm{g} / \mathrm{ml}$, and 2 strains as $2 \mu \mathrm{g} / \mathrm{ml}$ (Fig. 1 and 2). We detected the rate of rifampicin resistant VRE strains as $94.9 \%(37 / 39)$ and only two of the strains $(5.1 \%)$ were sensitive (MIC: $\leq 1 \mu \mathrm{g} / \mathrm{ml}$ ) to rifampicin ${ }^{11} . \mathrm{MIC}_{50}, \mathrm{MIC}_{90}$ and $\mathrm{MIC}_{\text {range }}$ values were $8 \mu \mathrm{g} / \mathrm{ml}, 16 \mu \mathrm{g} / \mathrm{ml}$, and $0.5-32 \mu \mathrm{g} / \mathrm{ml}$, consecutively. When we investigated HLAR and non-HLAR strains separately, we found that resistance to rifampicin among HLAR strains was $93.7 \%(15 / 16)$ and $95.6 \%$ (22/23) among non-HLAR strains. The MIC values of rifampicin for the HLAR strains were $8 \mu \mathrm{g} / \mathrm{ml}$, $32 \mu \mathrm{g} / \mathrm{ml}$, and $1-32 \mu \mathrm{g} / \mathrm{ml}$, and MIC values of nonHLAR strains were $8 \mu \mathrm{g} / \mathrm{ml}, 16 \mu \mathrm{g} / \mathrm{ml}$, and $0.5-16$ $\mu \mathrm{g} / \mathrm{ml}$, in the same order.

Gentamicin $\mathrm{MIC}_{50}, \mathrm{MIC}_{90}$ and $\mathrm{MIC}_{\text {range }}$ values for all strains were found as $64 \mu \mathrm{g} / \mathrm{ml}, 4096 \mu \mathrm{g} / \mathrm{ml}$, and $8-4096 \mu \mathrm{g} / \mathrm{ml}$, for HLAR strains: $4096 \mu \mathrm{g} / \mathrm{ml}$, $4096 \mu \mathrm{g} / \mathrm{ml}$ and $1024-4096 \mu \mathrm{g} / \mathrm{ml}$, and for nonHLAR strains: $32 \mu \mathrm{g} / \mathrm{ml}, 64 \mu \mathrm{g} / \mathrm{ml}$ and $8-64 \mu \mathrm{g} / \mathrm{ml}$ (Table 1 and 2).

Table 1. MIC values and susceptibility rates of daptomycin, rifampicin and gentamicin against 39 VRE strains

\begin{tabular}{|c|c|c|c|c|c|}
\hline \multirow[b]{2}{*}{ Antibiotics } & \multicolumn{3}{|c|}{ MIC values $(\mu \mathrm{g} / \mathrm{mL})$} & \multirow[b]{2}{*}{ Susceptible (\%) } & \multirow[b]{2}{*}{ Resistant (\%) } \\
\hline & $\mathrm{MIC}_{50}$ & $\mathrm{MIC}_{90}$ & $\mathrm{MIC}_{\text {range }}$ & & \\
\hline Daptomycin & 1 & 2 & $0.2-2$ & $39(100)$ & $0(0)$ \\
\hline Rifampicin & 8 & 16 & $0.5-32$ & $2(5.1)$ & 37 (94.9) \\
\hline Gentamicin & 64 & 4096 & 8-4096 & $23\left(59^{\star}\right)$ & $16\left(41^{\star \star}\right)$ \\
\hline
\end{tabular}

Table 2. MIC values of daptomycin, rifampicin and gentamicin against HLAR and non-HLAR VRE strains

\begin{tabular}{|c|c|c|c|c|c|c|c|c|c|}
\hline \multirow[b]{3}{*}{ VRE strains (n:39) } & \multicolumn{9}{|c|}{ MIC values $(\mu \mathrm{g} / \mathrm{mL})$} \\
\hline & \multicolumn{3}{|c|}{ Daptomycin } & \multicolumn{3}{|c|}{ Rifampicin } & \multicolumn{3}{|c|}{ Gentamicin } \\
\hline & $\mathrm{MIC}_{50}$ & $\mathrm{MIC}_{90}$ & $\mathrm{MIC}_{\text {range }}$ & $\mathrm{MIC}_{50}$ & $\mathrm{MIC}_{90}$ & $\mathrm{MIC}_{\text {range }}$ & $\mathrm{MIC}_{50}$ & $\mathrm{MIC}_{90}$ & MIC $_{\text {range }}$ \\
\hline HLAR (n:16) & 1 & 2 & $1-2$ & 8 & 32 & $1-32$ & 4096 & 4096 & $1024-4096$ \\
\hline Non-HLAR (n:23) & 1 & 1 & $0.2-2$ & 8 & 16 & $0.5-16$ & 32 & 64 & 8-64 \\
\hline
\end{tabular}




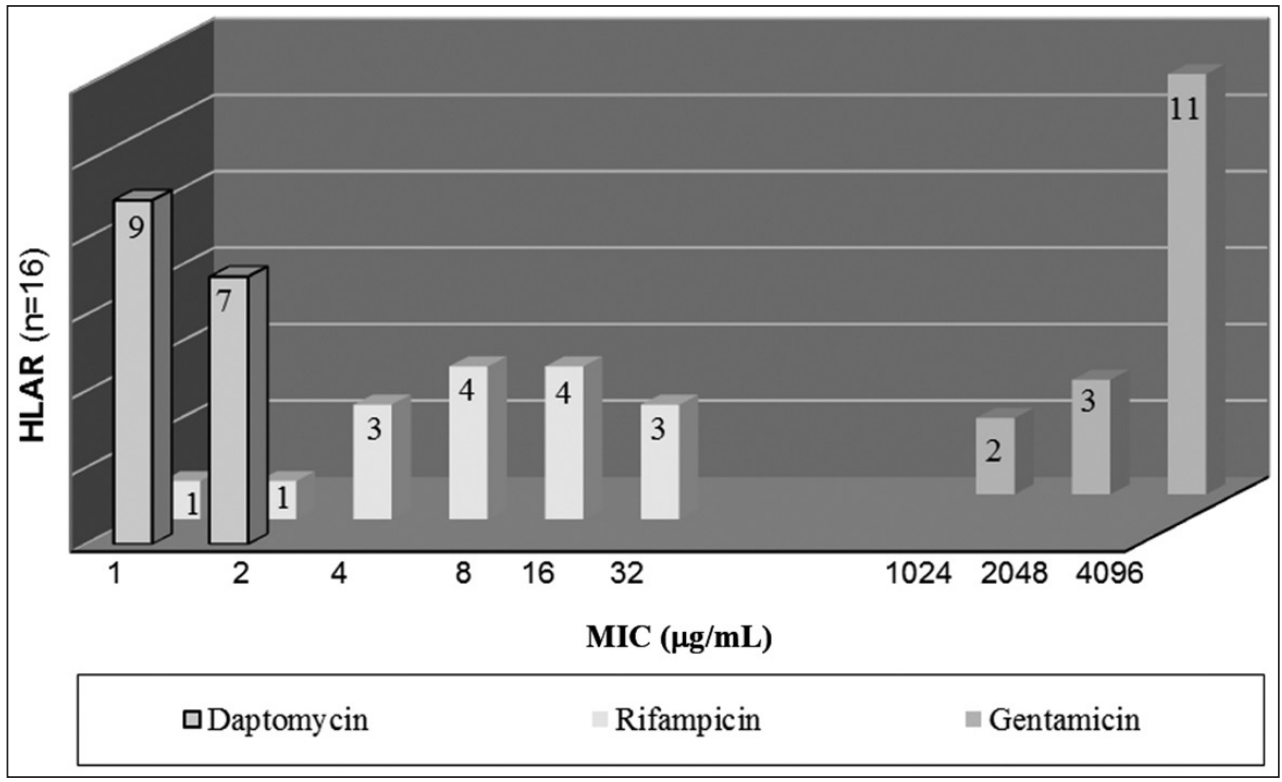

Figure 1. MIC distributions of antibiotics tested against HLAR VRE strains.

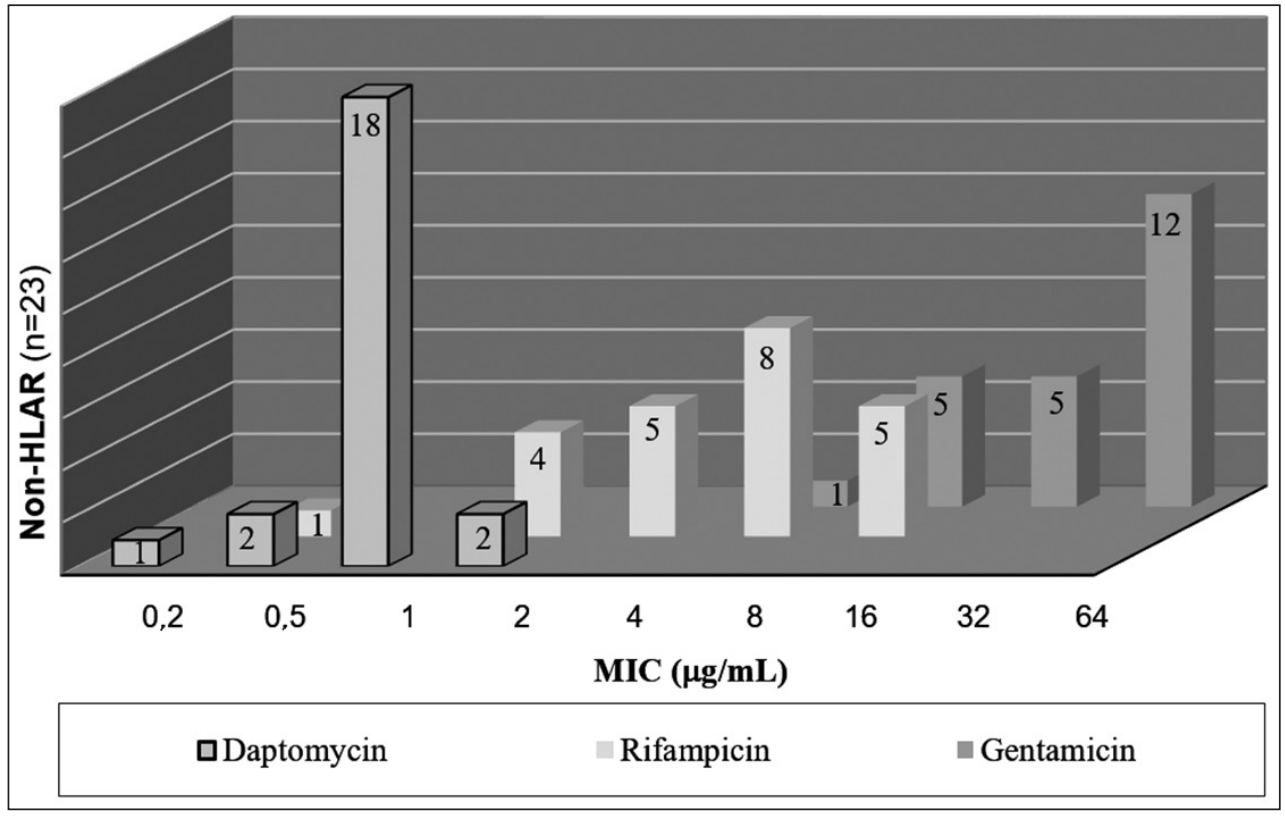

Figure 2. MIC distributions of antibiotics tested against non-HLAR VRE strains.

In-vitro activities of daptomycin in combination with rifampicin and gentamicin against all VRE strains are summarized in Table 3.

The FICI range values of daptomycin/rifampicin and daptomycin/gentamicin combinations for all VRE strains were identified as 0.155 to 1.5 and 0.375 to 2.0, respectively. The distribution of HLAR and nonHLAR strains with additive/indifference properties are demonstrated in Fig. 3. These outcomes indicate that daptomycin/rifampicin combinations had a 41.0\% (16/39) synergistic effect for the all VRE strains and an additive/indifference effect in 58.9\% (23/39). Sixteen of the HLAR VRE strains were evaluated further to the outcomes and daptomycin/rifampicin combinations' synergistic and additive/indifference effects were found as $50 \%(8 / 16)$. 
Table 3. The interpreted FICl results of the antimicrobial combinations against strains *

\begin{tabular}{|c|c|c|c|c|}
\hline \multirow[b]{2}{*}{ VRE strains ( $n=39$ ) } & \multicolumn{2}{|c|}{$\begin{array}{l}\text { Synergistic (\%) } \\
\quad(\mathrm{FICl} \leq 0.5)\end{array}$} & \multicolumn{2}{|c|}{$\begin{array}{l}\text { Add./ind. (\%) } \\
\text { (FICl >0.5-4) }\end{array}$} \\
\hline & $\mathrm{D}+\mathrm{R}$ & $\mathrm{D}+\mathrm{G}$ & $D+R$ & $\mathrm{D}+\mathrm{G}$ \\
\hline HLAR (n:16) & $8(50)$ & - & $8(50)$ & $16(100)$ \\
\hline Non-HLAR (n:23) & $8(34.8)$ & $2(8.7)$ & $15(65.2)$ & 21 (91.3) \\
\hline Total number (n:39) & $16(41.0)$ & $2(5.1)$ & $23(58.9)$ & 37 (95) \\
\hline
\end{tabular}

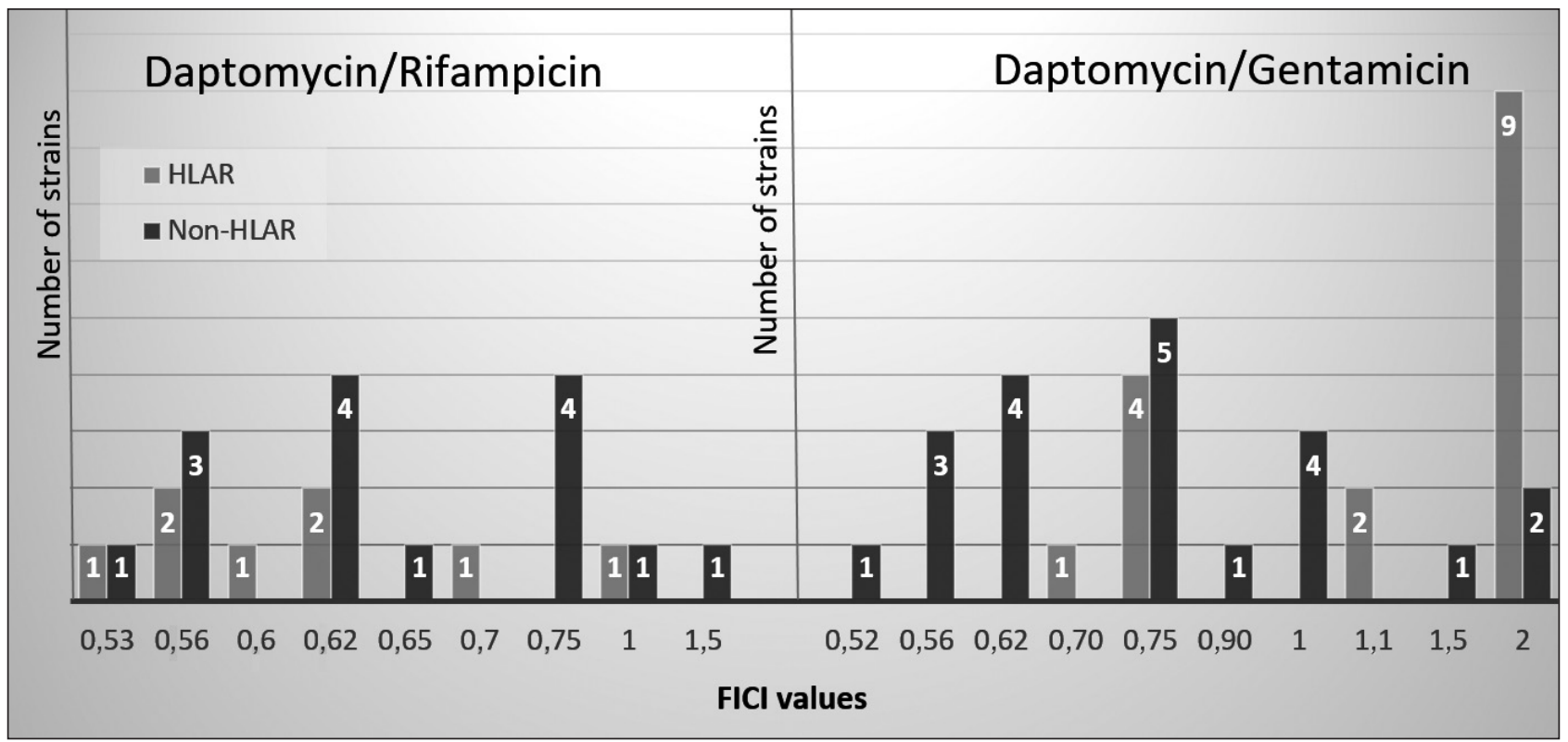

Figure 3. Distributions of add./ind. results ( $F I C l>0.5-4)$ obtained in combination of daptomycin with rifampicin and gentamicin against HLAR and non-HLAR VRE strains.

When the test results of daptomycin/gentamicin combinations were evaluated, all VRE strains had a $5.1 \%$ (2/39) synergistic effect and additive/indifference effect was about $95 \%$ (37/39). None of the HLAR strains had a synergistic effect but all had an additive/ indifference effect $(100 \%)$ with these combinations. On the other hand, $8.7 \%(2 / 23)$ of 23 non-HLAR strains had a synergistic effect and $91.3 \%(21 / 23)$ had an additive/indifference effect. We detected no antagonist effect neither HLAR nor non-HLAR VRE strains in any of the in-vitro combination studies.

\section{Discussion}

VRE colonisation in the bowel is a high risk for the development of nosocomial infections, particularly due to long-term antibiotic treatment or hospital stay for in-patients with chronic infections. There is an increasing prevalence of enterococcal infections among inpatients at present ${ }^{1}$. Antibiotics are used in combinations because they provide wide-spectrum treatment in serious infections. They also prevent or delay the emergence of resistant subpopulations of microorganisms. Additionally, the using of some antibiotics is restricted due to their toxic effects at effective doses; therefore, combinations of antibiotics such as aminoglycosides could provide a successful treatment option at lower doses $^{10}$.

Daptomycin has successfully been used in the treatment of serious infections of enterococcus strains including VRE ${ }^{14}$. Interaction of the combination of daptomycin with other antibiotics and its clinical benefits have been investigated for years ${ }^{15}$. Rifampicin effects by inhibiting DNA-dependent RNA polymerase of bacteria. Resistance to rifampicin develops as a result 
of many point mutations in the enzyme encoding $r p o B$ gene, which restricts the single use of rifampicin in treatments ${ }^{16}$.

In our study, resistance to rifampicin among VRE strains was detected as $94.9 \%$ (37/39); however, there was a $41.0 \%(16 / 39)$ rate of synergism and $58.9 \%$ $(23 / 39)$ additive/indifference in the daptomycin combinations. No antagonistic effect was detected against any of the strains.

Daptomycin attaches to the cytoplasmic membrane in subinhibitory concentrations that cannot kill the cell alone, but then opens channels for aminoglycosides and rifampicin to enter into bacterial cell ${ }^{10}$. Some studies reported that daptomycin promotes the entry of the hydrophobic antibiotic as rifampicin into the cell and as a result it was indicated that a combination of daptomycin with rifampicin may be an alternative in the treatment of VRE infections ${ }^{14,17}$.

Therefore, we investigated the interactions of daptomycin in combinations with gentamicin and rifampicin against VRE strains.

In a study, it was investigated that vancomycin and daptomycin combinations with rifampicin were studied separately against three $E$. faecium strains, which form biofilms, and rifampicin/daptomycin combinations were found to be more effective in decreasing the number of bacteria and minimizing resistance development ${ }^{18}$.

Various studies have reported that combinations of daptomycin/rifampicin have a $68 \%{ }^{17}$ and $57 \%{ }^{15}$ synergistic effect against VRE strains and the use of these combinations in treatment minimized resistance development ${ }^{18}$.

Enterococcus strains with high-level gentamicin resistance (HLGR) have been isolated worldwide and they constitute a significant amount of enterococus strains and cause major problems in treatment. This characteristic was first identified in E. faecalis strains in 1979 in France ${ }^{19}$. High level aminoglycoside resistance is constituted by numerous aminoglycoside modifying enzymes which have adenylating, acetylating and phosphorylating activities, carried by plasmids and transposons, and transmitted through conjugation.

A specific defect in the entering of gentamicin to the bacterial cell prevents synergy formation by the combinations in these strains. HLGR enterococcus strains are resistant to synergism ${ }^{10}$. The ribosomal modification mechanism has little effect on aminoglycoside resistance. A change on 30 S ribosome causes high resistance to streptomycin. The high level aminoglycoside resistance of enterococci prevents the synergistic effect between aminoglycosides and other antibiotics, which are effective on the cell wall, thus seriously restricting the synergistic interaction in the treatment of enterococcal infections ${ }^{20}$.

In a study, the FICI values of daptomycin and gentamicin combinations were investigated in 20 VRE strains using checkerboard checkerboard microdilution method, and the synergistic effect was found as $10 \%$ and no antagonist effect was detected ${ }^{21}$. In the same study, $\mathrm{MIC}_{50}$, $\mathrm{MIC}_{90}$ and $\mathrm{MIC}_{\text {range }}$ values of daptomycin and gentamicin were reported as $2 \mu \mathrm{g} / \mathrm{ml}, 4 \mu \mathrm{g} / \mathrm{ml}$ and $1-4 \mu \mathrm{g} / \mathrm{ml}$, and $4096 \mu \mathrm{g} / \mathrm{ml}, 4096 \mu \mathrm{g} / \mathrm{ml}$, and 4-4096 $\mu \mathrm{g} / \mathrm{ml}$, respectively. Outcomes of another study, in which combinations against biofilm forming VSE. faecalis and VRE. faecium were tested, revealed that gentamicin enhanced the activity of daptomycin but rifampicin delayed the activity of daptomycin ${ }^{22}$. Some combination studies of daptomycin/gentamicin revealed little synergistic effect against non-HLAR strains but had additive/indifference effects against most strains, and there were no combinations with antagonist effect thus they may provide benefits in treatments as parallel to our study ${ }^{15,23}$.

In summary, we argue that daptomycin/rifampicin combinations may be recommended for the alternative treatment of VRE infections. More efficient antibiotherapy could be provided in this way. In the meantime, resistance to new generation antibiotics such as daptomycin and rifampicin may be delayed or be prevented and the toxic effects of antibiotics can be limited. Daptomycin/gentamicin combination has no antagonist interaction but has a high-level additive/ indifference effect, and only a little synergistic effect against non-HLAR strains. These findings show that the efficacy of this combination is limited.

\section{Acknowledgement}

Scientific Research Projects Coordination Unit of Istanbul University supported this project (project no: 17092).

This study was presented as a poster (no: D876) in the "International Congress of Antimicrobial Agents and Chemotherapy, ICAAC, s.118, Washington DC, 2014 United States of America”.

We would like to thank Kadriye Gümüş and David F. Chapman for helps writing manuscript in english. 


\section{References}

1. Kamboj M, Chung D, Seo SK, et al. The changing epidemiology of vancomycin-resistant Enterococcus (VRE) bacteremia in allogeneic hematopoietic stem cell transplant (HSCT) recipients. Biol Blood Marrow Transplant 2010;16:1576-81.

2. Cattaneo C, Casari S, Bracchi F, et al. Recent increase in Enterococci, viridians streptococci, Pseudomonas spp. and multiresistant strains among haematological patients, with a negative impact on outcome. Results of a 3-year surveillance study at a single institution. Scand J Infect Dis 2010;42:324-32.

3. Pillai SK, Moellering RC Jr, Eliopoulos GM. Antimicrobial combinations, In: Lorian V. editor, Antibiotics in Laboratory Medicine, 5th ed., Philadelphia: Lippincott Williams and Wilkins; 2005:365-440.

4. Carlet J. Antibiotics must realy be protected. Oudega B. editor, FEMS Affiliates Letter, FEMS, June 2014.

5. Kristich CJ, Rice LB, Arias CA. Enterococcal infectiontreatment and antibiotic resistance. In: Gilmore MS, Clewell DB, Ike Y, Shankar N. editors, Source Enterococci: From commensals to leading causes of drug resistant infection. Boston: Massachusetts Eye and Ear Infirmary, 2014.

6. Salzer W. Antimicrobial-resistant gram-positive bacteria in PD peritonitis and the newer antibiotics used to treat them. Perit Dial Int 2005;25:313-9.

7. Hall DH, Steed ME, Arias CA, et al. Evaluation of standardand high-dose daptomycin versus linezolid against vancomycinresistant Enterococcus isolates in an in vitro pharmacokinetic/ pharmacodynamic model with simulated endocardial vegetations. Antimicrob Agents Chemother 2012;56:3174-80.

8. Steenberger JN, Alder J, Thorne GM, et al. Daptomycin: a lipopeptide antibiotic for the treatment of serious Grampositive infections. J Antimicrob Chemother 2005;55:283-8.

9. D'Costa VM, McGrann KM, Hughes DW, et al. Sampling the antibiotic resistome. Science 2006;311:374-7.

10. Pillai SK, Moellering RC Jr, Eliopoulos GM. Antimicrobial combinations, In: Lorian V editor, Antibiotics in Laboratory Medicine 5th ed. Philadelphia PA. Lippincott Williams and Wilkins; 2005:365-440.

11. Clinical and Laboratory Standards Institute. Performance standards for antimicrobial susceptibility testing 18th Informational supplement M100-S20, CLSI, Wayne, Pa; 2010.

12. Clinical and Laboratory Standards Institute. Methods for Dilution Antimicrobial Susceptibility Tests for Bacteria that Grow Aerobically: Approved Guideline, 7. Approved Standard M7-A7, CLSI, Wayne, Pa; 2006.
13. Odds FC. Synergy, antagonism, and what the chequerboard puts between them. J Antimicrob Chemother 2003;52(1):1.

14. Mohr JF, Friedrich LV, Yankelev S, et al. Daptomycin for the treatment of enterococcal bacteraemia: results from the Cubicin Outcomes Registry and Experience (CORE). Int J Antimicrob Agents 2009;33:543-8.

15. Steenbergen JN, Mohr JF, Thorne GM. Effects of daptomycin in combination with other antimicrobial agents: a review of in vitro and animal model studies. J Antimicrob Chemother 2009;64:1130-8.

16. Rice LB, Bonomo RA. Genetic and biochemical mechanisms of bacterial resistance to antimicrobial agents. In: Lorian V. editor, Antibiotics in laboratory medicine 5th ed. Lippincott Williams and Wilkins: Philadelphia PA; 2005:441-508.

17. Rand KH, Houck H. Daptomycin synergy with rifampicin and ampicillin against vancomycin-resistant enterococci. J Antimicrob Chemother 2004;53:530-2.

18. Holmberg A, Rasmussen M. Antibiotic regimens with rifampicin for treatment of Enterococcus faecium in biofilms. Int J Antimicrob Agents 2014;44:78-80.

19. Horodniceanu T, Bougueleret L, El-Solh N, et al. High-level, plasmid-borne resistance to gentamicin in Streptococcus faecalis subsp. Zymogeses. Antimicrob Agents Chemother 1979;16:686-9.

20. Leclercq R, Dutka-Malen S, Brisson Noel A, et al. Resistance of enterococci to aminoglycosides and glycopeptides. Clin Infect Dis 1992;15:495-501.

21. Snydman DR, McDermott LA, Jacobus NV. Evaluation of in vitro interaction of daptomycin with gentamicin or beta-lactam antibiotics against Staphylococcus aureus and enterococci by FIC index and timed-kill curves. J Chemother 2005;17:61421.

22. Luther MK, Arvanitis M, Mylonakis E, et al. Activity of daptomycin or linezolid in combination with rifampin or gentamicin against biofilm-forming Enterococcus faecalis or E. faecium in an in vitro pharmacodynamic model using simulated endocardial vegetations and an in vivo survival assay using Galleria mellonella larvae. Antimicrob Agents Chemother 2014;58:4612-20.

23. DeRyke CA, Sutherland C, Zhang B, et al. Serum bactericidal activities of high-dose daptomycin with and without coadministration of gentamicin against isolates of Staphylococcus aureus and Enterococcus species. Antimicrob Agents Chemother 2006;50:3529-34. 